\title{
Consensus
}

Volume 30

Issue 2 Festechrift: Faith Elizabeth Rohrbough

Article 14

$11-1-2005$

\section{Illuminating Luke: the infancy narrative in Italian Renaissance painting}

Diane E. Peters

Follow this and additional works at: http://scholars.wlu.ca/consensus

\section{Recommended Citation}

Peters, Diane E. (2005) "Illuminating Luke: the infancy narrative in Italian Renaissance painting ," Consensus: Vol. 30 : Iss. 2 , Article 14.

Available at: http://scholars.wlu.ca/consensus/vol30/iss2/14

This Book Reviews is brought to you for free and open access by Scholars Commons @ Laurier. It has been accepted for inclusion in Consensus by an authorized editor of Scholars Commons @ Laurier. For more information, please contact scholarscommons@wlu.ca. 


\section{Illuminating Luke:}

\section{The Infancy Narrative in Italian Renaissance Painting}

Mikeal C. Parsons and Heidi J. Hornik.

Harrisburg, PA: Trinity Press International, 2003.

164 pages, \$22.05 Softcover

Since the mid-1960s scholars and clergy have paid increasing attention to the role of the visual arts in the theology and liturgy of the church. Illuminating Luke, written by a biblical scholar in collaboration with an art historian, focuses on the analysis of four paintings based on texts from early chapters of the Gospel of Luke: Leonardo da Vinci's The Annunciation of ca. 1473-75; Jacopo Pontormo's The Visitation of 1514-16; Domenico Ghirlandaio's The Nativity and Adoration of the Shepherds of 1483-85; and Ambrogio Lorenzetti's The Presentation in the Temple of ca. 1342.

The opening chapter provides background on Luke, and discusses legends which identify him as a physician and as the painter of the earliest portraits of the Virgin Mary. Each subsequent chapter discusses one painting, situating it in its cultural, political, and theological context, and exploring its meaning, both for the original viewers and for our contemporary community of faith. Analyses include an overview of the Biblical passage on which the work is based, a summary of the subsequent history of interpretation of the text, a profile of the artist, stylistic and iconographic analysis of the painting, and hermeneutical reflections.

Illuminating Luke is amply illustrated, with colour reproductions of the four main works, and thirty-five supplementary black and white figures. While the book would be most meaningful to those with some background and interest in art history, extensive footnotes refer readers to more detailed sources and explain many of the artistic terms used. The notes also provide English translations of citations. There is a selected bibliography and a detailed index.

The authors point out that the title of the book is an allusion to the practice among medieval scribes of visually illustrating a manuscript being copied, and thus providing additional interpretive resources for the reader. Art work can draw attention to details of a story often neglected in literary interpretations of a text, as well as reflect the artists' own theological reflections through their use of symbolism. While the works discussed in Illuminating Luke were 
shaped by the specific context of the Italian Renaissance, a study of this type serves as a broader reminder to pastors, students, and general readers of the way in which the arts can contribute to the development and understanding of Christian faith, especially in our modern visually-oriented culture.

Mikeal C. Parsons is a professor of religion at Baylor University in Waco Texas, and is the author of The Departure of Jesus in LukeActs and co-editor of Rethinking the Unity of Luke and Acts. Heidi J. Hornik is an associate professor of art history at Baylor University, and the co-editor, with Mikeal Parsons, of Interpreting Christian Art.

Diane E. Peters

Wilfrid Laurier University / Waterloo Lutheran Seminary

Waterloo, Ontario

\section{Missions, Nationalism, and the End of Empire}

Brian Stanley, Editor

Grand Rapids, MI: William B. Eerdmans Publishing Company, 2003

313 pages, \$46.19 Softcover

At a time when Christians become increasingly aware of powerful religious alternatives to Christianity both at home and abroad, churches must give more seriously critical attention to the meaning of their missionary work. Part of this task involves a serious examination of the history of Christian missions in a world that has passed from colonial imperialism to newer, more complex relations between western countries and the southern poorer nations that constitute the overwhelming majority of the world's population. This history leaves a legacy that, if unexamined, will continue the toxic behaviour of our past efforts. At the same time we can learn from more positive examples that emerge from our former practices. I believe that Brian Stanley's Missions, Nationalism, and the End of Empire makes a positive step toward such a fruitful analysis.

To be sure, the book suffers from virtually all examples of its type. It is a product of an academic conference where papers were presented by a variety of scholars on the common theme of missionary history. Consequently the entries reflect a fairly wide variety of topics (some 